\title{
War Heroes and Pacifists on the Same Front: Re-reading Heroism in Two Imperial War Memoirs
}

\author{
Cristina Pividori / Andrew Monnickendam \\ Autonomous University of Barcelona \\ MariaCristina.Pividori@uab.es / Andrew.monnickendam@uab.es
}

\begin{abstract}
This article explores the notion of heroism in Victorian war literature by analyzing the figure of the soldier-hero in two imperial war memoirs: Captain Mowbray Thomson's The Story of Cawnpore: The Indian Mutiny and John Pearman's The Radical Soldier's Tale. While The Story of Cawnpore is an emblematic example of what we call the Victorian hero myth, that is, the effective merging of traditional heroism, war as adventure and imperialism in mid-to late-nineteenth century Britain - The Radical Soldier's Tale appears to posit an alternative to this widely accepted view, challenging its assumed universality and immutability. By analyzing Pearman's innovative revision of heroism, in contrast to Thomson's more conventional representation of the theme, this article attempts to illustrate both the traditional construction and a possible re-reading of the subject taking place in the same period. In order to do so, we focus on the three main aspects around which the representation of the nineteenth-century soldier-hero is articulated: the consolidation of traditional heroic manhood in the context of imperial war, the complex social justification of war and the demonization of the Other as a way of validating the heroic self. Particular attention is given to the fact that Pearman's shift towards a more complex appreciation of the heroic subject appears to anticipate similar patterns occurring in the literature written during and after World War One.
\end{abstract}




\section{Introduction}

"I want a hero," Byron famously advertises in the opening of "Don Juan," and he seems to express a common ground of shared concerns that gained increasing prominence as Victorianism made way for the twentieth century in Britain. It would be no exaggeration to say that hero-worship was an inherent disposition in Victorian times. In one of the lectures that would frame the discourse on heroism for the next century, On Heroes, Hero-Worship and the Heroic in History, Carlyle (2000: I-10) refers to the nature and necessity of hero-worship and its centrality in the popular imaginary: "Heroworship is the deepest root of all; the tap root, from which in a great degree all the rest were nourished and grown." Indeed, Carlyle's remark gives a concise, though distinctive summary of the point of view from which our study on war heroism begins: the admiration of the deeds of the great men was the outward manifestation of a set of received values and ideas that constituted the core identity of Victorian Britain.

The figure of the hero was the ideal projection of the common man's hopes having gone through the vicissitudes of life with somehow greater ease and valour. Religious prophets and priests, men of letters and, as the demands of imperialism grew nationwide, fundamentally warriors, were regarded as the archetypal men of the era, the emblem of manhood and virtue: "They were the leaders of men, these great ones; the modellers, patterns, and in a wide sense creators, of whatsoever the general mass of men contrived to do or to attain" (Carlyle, 2000: I-7). Whether prophets priests or poets, heroes were identified by their military strength. Courage was "the chief recognised virtue" (Carlyle, 2000: III-87), the most consistent criterion for understanding nineteenth-century heroism. ${ }^{1}$ As MacDonald argues, "Carlyle provided a thesis of masculine strength" (1994: 54) which had a profound effect on popular consciousness as "heroic myths were primarily military" (MacKenzie, 1989: 113) and, in the context of the expanding empire, sought to justify military action and meet the moral needs of the period.

Hero-worship and heroic virtue pervaded British popular imagination and became the most representative aspect of what we call the 'Victorian hero myth' - that is, the effective merging of traditional heroism, war as adventure and imperialism in certain social constructions and their literary projections in mid-to late-nineteenth century Britain. We use the word myth in the Barthesian sense, as myth turned the problematical into a natural and accepted truth. In other words, the Victorian hero myth justified empire and "turned moral ambiguity into unquestioned certainty" (MacDonald, 1994: 89). The rather grandiloquent representation of military feats, helped both distinguish heroic standards of conduct and counter doubts arising from the unsavoury aspects of the imperial frame of mind: "in metaphorical terms, the life of the hero served its purpose: it was a distraction from the harsh facts; presenting a different and more dramatic reality, it shifted the argument around" (MacDonald, 1994: 81). War heroes were not only superior beings but also "the product of social needs and forces" (Ouimette, 1974: 13), as their lives reinforced and legitimised imperial reality. The 
soldier who sacrificed his life for his country, then, became one of the clearest and most widely advertised images of the truly masculine man.

The Victorian hero myth provided a pattern-book of heroism based on classic examples from the heroic past - that is on the personal and abstract qualities of the legendary heroes described in Arthurian legends and much later systematized in archetypal interpretations, such as Otto Rank's The Myth of the Birth of the Hero (1909), Lord Raglan's The Hero (1936) and Joseph Campbell's The Hero with a Thousand Faces (1949). Interestingly, Campbell draws a recurring pattern in myths and legends that he calls "monomyth" (Campbell, 2004: 28). The main character in Campbell's "monomyth" is the hero archetype who "ventures forth from the world of common day into a region of supernatural wonder: fabulous forces are there encountered and a decisive victory is won: the hero comes back from this mysterious adventure with the power to bestow boons on his fellow man" (2004: 28). In the face of danger and hardship or from a position of weakness, these legendary heroes exhibit courage and the will for self-sacrifice for some greater benefit. Although women are not explicitly excluded from Campbell's scheme, it is evident that the spirit of the journey allows only for male heroes (Segal, 2000: 8). Homer's Odysseus and Achilles, Virgil's Aeneas, Wordsworth's Happy Warrior and Tennyson's hero-king may equally perform, for the most part, the Campbellian heroic function.

The same can be said of the representation of the soldier-hero in Victorian war literature. Sir Henry Havelock, Generals Gordon, Wolseley, Roberts, Kitchener and Col. R.S.S. Baden-Powell, among others, became the subject of the most widely read imperial biographies, being treated as moral characters, paradigms of the time, symbols of both military skill and decorum. Referring to what he regards as "the exemplary life," Mackenzie argues that "its power is conveyed not only by texts but also through icons. Such an iconography develops its influence through repetition, and significant ideas can be projected through multiple and parallel imaging" (Mackenzie, 2000: 84). This way, the story of the imperial hero was presented in its stereotypical form, in "clear lines and hard concepts"” (MacKenzie, 1989: 115). Most of the circulating stories were not concerned with "the real flesh and blood characters with names and addresses and graves, but [with] the representations of them" (Attridge, 2003: 3). Each new hero seemed to repeat and validate the patriotic acts of his predecessors as they all "tended to merge into a single persona, reflecting the heroism of the nation" (MacDonald, 1994: $51)^{2}$

Although popular biographers did their part to sustain the Victorian hero myth, foster hero-worship and impress the impressionable with the deeds of the greatest British warriors, it was the genre of adventure romance that best channelled both "the feeling of excitement" about the British imperial myth and "its expression in literature" (Green, 1980: 5). ${ }^{3}$ As MacDonald (1994: 62) claims, "bravery in battle, gallant action, facing savages for Christ, emulating Gordon, the great Christian hero", both the martial and the evangelical spirit of the age were set out as a lesson to be taught. Comfortably detached from war itself, Victorian readers felt a widespread interest in military combat, scenes of bloodshed and Christian courage that kept on rising as the century progressed. 
Though initially abandoned to the category of sub-literature, the 1880 s witnessed the peak of the adventure story. It was from the hand of Sir Henry Rider Haggard, Rudyard Kipling, R.L. Stevenson, Conan Doyle and the popular G.A Henty and W.E Johns that "[the genre of adventure romance] was raised to a higher literary status by the much acclaimed revival of Romance as a category of the Novel, in the 1880's" (Rutherford, 1978: 16).

Among the heroic adventure narratives mentioned above are the stories told of the colonial wars of empire. Captain Mowbray Thomson's The Story or Cawnpore: The Indian Mutiny 1857 and John Pearman's The Radical Soldier's Tale are two of the many testimonies written by British imperial soldiers in India. ${ }^{4}$ Yet, these two war memoirs are exceptional for two reasons: gender interacts with class and nationality in such a way that not only do the texts provide radically opposite accounts of relatively similar historical circumstances, but their visions of heroic masculinity are distinctive and differently approached. Captain Mowbray Thomson' The Story of Cawnpore: The Indian Mutiny 1857 is emblematic of the Victorian hero myth: the literary response to war heroism is both typical of heroic mythology and essentialist gender discourses. ${ }^{5}$ Framed in a manner that leads to jingoistic feelings and reverence for the British crowd, the memoir contributes to the development of a new genre - the "Mutiny Fiction."

While it is far beyond the scope of this study to carry out an in-depth analysis of all the literary responses to the Indian Mutiny of 1857, we will explore - through a detailed analysis of the representation of the soldier-hero - the articulation of the Victorian hero myth in Thomson's The Story of Cawnpore, which seems to be radically questioned, as we shall see later in the article, by contemporary soldier-writer John Pearman. John Pearman's The Radical Soldier's Tale puts into question the war literature of his time, attempting a departure from the Victorian hero myth and challenging its assumed universal validity. While Thomson depicts the tradition of masculine heroism based on heroic archetypes, Pearman challenges the traditional equation, which he defines as the "the Cannon, the Sword and Bayonet mounted with Gold" (Steedman, 1988: 239), suggesting that, "behind and alongside the bluster of imperialist language, and sometimes pulsing at the heart of it, is anxiety and introspection" (Attridge, 2003:3). ${ }^{7}$

Even though the representation of traditional war heroism recurs in the fiction of many soldier-writers in India, Thomson's The Story of Cawnpore will be used as an illustrative example of this curious blend of religion, politics and patriotism that came to be seen as characteristically Victorian, but also, and above all, as a contrast to Pearman's oppositional re-writing of the myth. This article will thus offer a detailed analysis of the representation of the soldier-hero in both Thomson and Pearman's memoirs to give new insights into the literary articulation of war heroism and a reading between the lines of the Victorian hero myth in both texts, with attention, of course, to its gender dimension. We will focus on the three main aspects around which the representation of the Victorian soldier-hero is articulated: the shaping of heroic masculinity as an imperial construction, the validation of violence as a socially approved and necessary means in the defence of British civilization, and the conflicting tension between self-Other in terms of the ally-enemy distinction on the other. 
Particular attention will be given to Pearman's innovative understanding of the enemyOther that not only leads to a reinterpretation of war heroism but appears to anticipate similar patterns occurring on a larger scale in the literature written during and after World War One.

\section{The Victorian Hero Myth in the Texts}

\subsection{Captain Mowbray Thomson as the Imperial War Hero}

Captain Mowbray Thomson was a member of the military elite in charge of Cawnpore, a British military station in Bengal. In July 1857, mutinous Sepoys besieged the British cantonments and after the - ultimately treacherous - passage to the river offered by the rebel leader, Nana Sahib, massacred over two hundred English men, women and children. ${ }^{8}$ Captain Thomson was one of the four survivors of the siege and the only one to give a first-hand testimony of the tragic events. He endured all the fighting and the privations of the besieged cantonment then escaped down the Ganges eventually reaching the safety of the court of a loyal Indian chief.

The Story of Cawnpore describes an armed conflict that, in itself, was distinctive and emblematic in British war history. Not only did the Indian Mutiny contribute to a new image of the army, but it also marked the rise of the Victorian hero myth to its highest pitch and its unquestionable prevalence until World War One. In this context, Thomson's war memoir can be read both as an imperial text, a "revenge response" to the Indian Mutiny, ${ }^{9}$ and as representative of the first steps towards the "hero industry" narratives that would gain predominance in the $1880 \mathrm{~s} .{ }^{10}$ Predictably, Thomson employs the romance format to portray a warrior who, in accordance with Northrop Frye's "high mimetic mode," is fully human but "superior in degree to other men" (Frye, 1970: 33). The soldier-heroes in The Story of Cawnpore arrive in the story with the qualities that enable them to cope with any problem, and posses exactly the same qualities at the end when they emerge triumphant. In this way, Campbell's hero's journey - Van Gennep's (1909) three stages or rites of passage are translated by Campbell into separationinitiation-return - can be easily adapted to the greatest heroic deeds recollected by Captain Thomson in his memoir, among them the narration of the military feats of the great Sir Henry Havelock, General Wheeler, Captain Moore and Captain Williamson, just to mention some of the most emblematic heroes of the Indian Mutiny mentioned in the memoir. Thomson himself, being one of the few survivors of the siege of Cawnpore, seems to travel a circular journey from his place of origin and back again, and to obtain in his return the social reward he deserves and his relationship with the social order reestablished. If regarded as a typically heroic text thus, The Story of Cawnpore may be found monotonous and uninteresting because of its stereotypical simplicity. Thomson's soldier-heroes all appear to behave similarly. Altruism, self-sacrifice and courage are presented as the only possible virtues and therefore characters develop as falsified or sentimentalised stereotypes. 
From a gender perspective, these heroic stereotypes can be seen as instrumental in the construction of desirable masculinities in Victorian Britain. As Braudy (2003: 349) argues, nineteenth century masculinity was a fixed concept that demanded clear positioning due to the constant threats against the colonial frontiers: "men should be men and women should be women." British imperial wars required exaggerated and clean-cut masculinities as deviation could bring about military defeat. Thomson's maledominated anecdotes seem to endorse this gender essentialist model by depicting masculine traits as unchanging, ahistorical and innate essences. The portrayal of the soldiers resisting the siege of Cawnpore certainly functions as an illustration to this: the repression of emotion while enduring pain, the view of violence and aggression as appropriate manly feelings and the solidarity with the weakest - women and children are essential to Thomson's recollections of his comrades' deeds. British soldiers are represented as "disinterested even in death" (Thomson, 1995: 87) and determined "to shelter the women and children to the latest moment" (Thomson, 1995: 85).

These remarkably powerful figures who stand and fight alone apply to what is regarded as the Victorian ideal of "manliness:" "Manliness was the most clearly articulated indicator of men's gender in the nineteenth century. Always used in the singular, it implied that there was a single standard of manhood, which was expressed in certain physical attributes and moral dispositions" (Tosh, 2004: 2). War and violence were nothing but chances to confirm or recreate the existence of these fixed characteristics or given attributes. Of Lieutenant Delafosse's valour under fire, Thomson says:

....and how to extinguish the flames was a problem requiring no common skill to solve, when my friend, with the coolest self-possession imaginable, went to the burning gun, and lying down under the fiery mass, pulled away splinters of the wood, and scattered earth with both hands University Presson the flames. [...] The character of this exploit will be better appreciated when I add, that all the while, six guns were playing their 18 and $24-$ pounders around the spot. (Thomson, 1995: 138-139)

Thomson's text presents abundant images like this. The figure of the soldier stands for a sense of heroic manhood that is recreated as nerve and physical aptitude and grace under strain. Violence becomes inextricably linked to warrior characters as "part of the masculine aesthetic" (Tiger, 1969: 211). It is manly to be strong, the strong conquer, and victory is better than defeat. As Kimmel puts it, "masculinity must be proved, and no sooner is it proved that it is again questioned and must be proved again" (Kimmel, 1996: 164).

After the second attack on Cawnpore, which may be described as a turning point for the army of avengers and the defeat of the rebels, the irreproachable conduct of General Windham is tirelessly praised - "his great personal prowess, his gentlemanly manners ... his capacities for command ... [and an] overboldness sustained in him by a needful amount of prudence and caution" (Thomson, 1995: 238) - as he endures with courage and stoicism one of the harshest rebel attacks after the first siege of Cawnpore. These repeated representations of violent - but charming - behaviour tend to universalize a 
view of male gender roles understood as personal accomplishment, as something to be made, which is essentially connected to the imperialist dogma and remains unchanged until the two world wars as the "traditional or dominant model of masculinity" (Buchbinder, 1994: 8)

The result of this single-minded notion is a definition of heroic manhood in terms of binary oppositions or extremes. The black and white, male and female, University Pressper class and lower class opposites underpinned the imperial ideology and justified the dominance of one over the other in the grounds of 'moral' superiority. When discussing the ambiguities and paradoxes at the heart of the adventure stories, Hourihan (1997: 16) claims that

the meanings of hero stories depend University Presson these related pairs of signifiers which express the dualistic structure inherent in Western thought, a pattern of values which naturalizes the dominance of the European patriarchal elite and the subordination of other cultural groups, other social classes, women and nature.

This way, heroes can be easily distinguished from the Other - females, cowards and enemies - appearing either as the protectors or seducers of women or as the feared enemies of other men (Buchbinder, 1994: 21; Mosse, 1996: 9; Braudy, 2003: 24). In the context of this Manichean confrontation, those who are defined as heroes - including Thomson himself - are made to praise forms of heroism that not only exclude women but - because of their racial, class and ideological component - also exclude large numbers of men. This process of Othering then can only be possible through the repression or destruction of anything that threatens the stable masculinity of the individual. For that reason, the figure of the soldier is solely perceived as a unified whole of body and soul immune to external attacks. Referring to the British self-Other dichotomy, George Mosse (1996: 56) says:

Those who stood outside or were marginalized by society provided a countertype that reflected, as in a convex mirror, the reverse of the social norm. Such outsiders were either those whose origins, religion, or language were different from the rest of the population or those who were perceived as asocial because the failed to conform to the social norms.

Among those stepping distinctly outside the normative ideal of manliness were the cowards. They were deemed to be inadequately masculine as they failed to measure University Press to some standard of proper male physic-psychological behaviour either because they were physically weak or because they were suspected of avoiding suffering, the spectacle or even the very idea of pain. In traditional terms, being a coward was like being morally effeminate and being a soldier or a policeman was the antithesis of morally effeminate. According to George Mosse, "it was the so-called unmanly men, however, who provoked the deepest anxiety among those who were part of normative society, and who, while possessing all the traits of the outsiders, in addition seemed to have crossed the barrier of gender" (1996: 66). Like the homosexuals or the unwomanly women, cowards were not only countertypes, but they 
were also the most readily visible and frightening examples. Not surprisingly, the stereotype of the coward remains astonishingly stable in The Story of Cawnpore, just as that of true manliness undergoes no fundamental change:

I deeply regret, however, to have to record the fact that there was one officer of high rank, and in the prime of life, who never showed himself outside the walls of the barrack, nor took even the slightest part in the military operations. This craven-hearted man, whose name I withhold out of consideration for the feelings of his surviving relatives, seemed not to possess a thought beyond that of preserving his own worthless life.... It was positively a relief to us when we found that his cowardice was unavailing; and a bullet through the boat's side that despatched him caused the only death that we regarded with complacency. (Thomson, 1995: 90)

The officer's attitude is associated by Thomson with weakness, passivity and vulnerability, aspects assumed in women but not encouraged in men - and even less in soldiers.

But not only did courage, strength and resistance distinguish the hero from the Other, the main factor for the prolonged British rule in India was the British belief in their racial superiority over the enemy: "rulers and ruled were arranged hierarchically as superior and inferior races, as civilized and uncivilized" (Mukherjee, 1990: 93). British superiority was expressed by treating Indians as "incarnate fiends" (Thomson, 1995: 103) and "savage men" (1995: 90), and denying them humanness and goodness: ${ }^{11}$

While on our side every interest of humanity and patriotism, and every instinct of honour and existence, impelled us to perseverance in the defence, on the side of the enemy the most mendacious fabrications were put forth, to stir University Press the bigotry and hate of the natives. (Thomson, 1995: 142)

This type of distinction served the purpose of creating not only images of the Other but also images of the heroic-self, which in the case of the narratives of revenge produced after the Indian Mutiny, dealt with the representation of British imperial identity, personified, of course, in the white male British soldier. The person of Sir Henry Havelock was made to embody the qualities of compassion and stoic endurance that made him the unquestionable figure on the side of the heroes: "the name of 'Havelock' was invested with idealized projections of positive value, his heroization being a product of the same psychic splitting that demonized Nana Sahib" (Dawson, 1994: 98). The epic image of Havelock becomes the narrative axis in Thomson's memoir and remains an intertextual presence of whom and what a hero should be and stand for. Nana Sahib, on the other hand, is transformed into the evil other condensing all the most shocking and threatening aspects of the Rebellion:

It will be remembered by my readers that no relief reached Cawnpore until three weeks after the capitulation, when the invincible Havelock wrested the cantonments from the treacherous Nana. Would that his unparalleled feats of valour had met with the reward 
which in his large hear he so much coveted! - the privilege of rescuing some of his countrywomen from the fangs of their brutal murderer. (Thomson, 1995: 116)

It seems as if Havelock himself was single-handedly responsible for achievements that were actually won by a force of hundreds. Havelock's triumph over Nana Sahib is seen as the expression of the will and intentions of the British. Rather than engaging directly with the Indian Mutiny, Thomson responds to one of its men - Nana Sahib whom he perceives as an alarming threat. In order to fight this threat, Thomson retreats to national hero-worship and to old heroic convictions.

Apart from the binary oppositions between the heroic-self and the Other, there is the religious component. The acceptance of violence for the good of the nation - "war was clearly necessary to maintain the empire and allow God's work to take place" (Paris, 2000: 17) - helped to justify military action and elevate soldiers to national masculine ideals. The image of man as a tough and ruthless soldier, on one hand, and as the devoted Christian, on the other, reflected not only the view British society had of itself, but also its anxieties: "if the empire was in danger, men must be produced who were tough, realistic, un-squeamish and stoical" (Tosh, 2004: 194). The logic was clear and appeared to be irrefutable: Christians were being threatened by non-Christians; therefore, the resources that enabled the British to win were, inevitably, seen as uniquely Christian. This combination of religion, politics and patriotism that emerged under the name of Christian militarism was embodied in the figure of Sir Henry Havelock himself, "a staunchly puritan man of blood" (Anderson, 1971: 51) and the Christian Soldier par excellence: "Christians made the best soldiers; and this was peculiarly the accomplishment in an indirect way of the Indian Mutiny" (Anderson, 1971: 49). In fact, it is Sir Henry Havelock himself who describes the recovery of Cawnpore in religious terms: "By the blessing of God, I recaptured this place yesterday" (qtd in Thomson, 1995: 214). Havelock's impeccable military career proved that Christianity and devoted soldiering were not incompatible. More importantly, together with Charles George Gordon of Karthoum, ${ }^{12}$ he encompassed all the qualities manliness, chivalry, devotion to duty and self-sacrifice - that made him a powerful symbol of the Victorian Christ.

The introduction of the notion of Christian militarism in Victorian literature then contributed the necessary moral component to the ideal of the strong, aggressive war hero and provided violence with both social justification and a sacred face. What is more, it provided a coherent explanation of why the British were exercising their power in such a range of remote places. According to Anderson, this is not only due to the official moral framework that was given to the duty of soldiering, but also to the emergence of religious organizations - the Salvation Army, the Church Army and the Boy's Brigade - that imitated the "military discipline, titles, uniform and accoutrements" of the army (1971: 66). The essential quality of Victorian Christian militarism is that it seemed to offer an acceptable alternative for a society that had to come to terms with imperialist war, but yet exhibited clear traits of moral integrity and ethics. 
Thomson uses Christian militarism as a means to justify the desire for revenge that started to emerge in the early responses to the news from Cawnpore. Essentially, he simplifies facts by reducing matters to straightforward oppositions between good and evil, victims and villains. Speaking of the situation of the defeated mutineers in 1857 , he says:

They have acknowledged the sceptre of Queen Victoria, and have become constituents of the great British Commonwealth. Under the sanction of unrestricted commerce, the vast natural resources of the land will multiply beyond all conception; hideous superstitions will give place to a pure faith; righteous laws will rectify tyrannic abuses; science will clear the jungle and irrigate the desert. There is room enough here for all the adventurous heroism and indefatigable perseverance that ever made the name of England great. (Thomson, 1995: 262)

The use of violence is justified by suggesting that even the defeated Indians have finally welcomed and legitimised British rule. Clearly, it is Britain's duty to rule. The British Empire is presented as the greatest force for good the world has ever seen; Thomson himself feels he is one of the custodians of the British Empire and as such, emphasizes his sense of duty, responsibility and self-sacrifice. He preaches what appears to be the dominant views and values: British superiority and the white man's duty towards inferior races. As Eldridge (1996: 20) points out, "such expressions of a sense of mission, of obligations incurred and responsibilities to be shouldered, as well as outright pride in British achievements overseas are constantly made throughout the nineteenth century." Readers are, to a significant extent, encouraged not only to admire and imitate heroes, but to view the empire as a vehicle of self-achievement, fulfilling the British race's divine mission to civilize and to govern a large part of humanity.

From the issues discussed in this section, there is enough evidence to support the claim that the figure of the soldier-hero in The Story of Cawnpore draws faithfully and predictably on the notion of the Victorian hero myth. Being a typical representative of hegemonic masculinities, an eyewitness to the tragically famous events and one of the first to respond to them, Thomson's text characterizes, like no other, the dominant discourses of his time.

\subsection{John Pearman: War Hero or Radical Pacifist?}

John Pearman was a working-class man who joined the King's own Light Dragoons in the 1840s and was later drafted to India. As part of the Army of the Punjab, he fought in the Sikh Wars and took part in the British annexation of the Punjab territories. ${ }^{13}$ In 1857, after leaving the army, he became a constable in Buckinghamshire and, following his retirement in 1881, started to write his memoir. The Radical Soldier's Tale (Steedman, 1988) is both the story of Pearman's life as a soldier and a policeman and the exposition of his beliefs on the political, military and religious institutions of his time. Yet, his soldiering years in India became a turning point in his personal development and the major determinant of his decision to write about his life, as it is 
this period of his life he wrote about most extensively. In fact, writing The Radical Soldier's Tale seemed to allow Pearman to reinterpret the story of his life in the light of the imperial circumstances of the $1880 \mathrm{~s}$, that is, during Britain's increasing imperialist predominance. In any case, as the historical events Pearman describes precede The Story of Cawnpore, the dating of Pearman's memoir in the 1880s has been of crucial importance in the selection of the two texts under discussion, as Pearman wrote his story with the Mutiny, Christian Militarism and the hero myth literature in mind. It is, then, possible to foresee subsequent developments in the soldier's description of incidents and events prior to the Indian Mutiny.

Though written in the 1880s - during the peak of the hero industry narratives - The Radical Soldier's Tale attempts a departure from the Victorian hero myth. What makes this memoir particularly interesting for analysis is in fact the contradictions and different shades of meanings it uncovers. As the 1988 editor of the text argues, there is a "tension that John Pearman came to see lying between experience and explication" (Steedman, 1988: 18). In effect, the memoir develops into an ambiguous narrative that blurs the boundaries between the description of military experience and its interpretation. The most obvious evidence of this is the inconsistencies between the radical soldier's enthusiastic beginnings at the King's own Light Dragoons and his later condemnation of British imperialism: while he admires the splendour of the army ready for battle in the first part of the memoir - "I sat on my horse and Looked at the two armies. It was a lovely sight" (Steedman, 1988: 128) -in the second half, he criticises militarism as the emblem of imperialism - "away with Kingcraft all this cant the Idols are the Cannon the Sword and Bayonet mounted with Gold" (1988: 239).

Such narrative fracture - and the ambiguities it entails - allows for the text to be divided into two ideologically distinct parts: Pearman's soldiering years (1843-1857) on the one hand, and his life as a policeman in the Buckinghamshire Constabulary (18571881) on the other. University Press to the moment Pearman leaves the Regiment in 1857, he writes a military memoir similar - in content and narrative form - to most narratives of the Sikh Wars written by other private soldiers. ${ }^{14}$ The second half of the Memoir, however, "becomes a written radical political argument, into which [Pearman] inserts autobiographical detail at various points, usually for the purposes of illustration" (Steedman, 1988: 18). In other words, Pearman uses the romance format in the first part of the memoir, while in the second - when the soldier moves from the retelling of experience to its explanation - he becomes immersed in the exploration of the complexity of his war experience.

Referring to Pearman as a soldier and a policeman, but also as a radical and a republican deeply aware of his working-class condition, Steedman (1988: 19) claims that the soldier is somehow different from the rest of his contemporaries: "Pearman was not a simple man, and the ideas he worked University Presson in his writing are not simple either." His memoir, thus, can be studied in terms of an anxious struggle between the rhetoric of imperial heroism and the actual experience of war confronting the soldier with feelings that cannot fit within the Victorian hero myth standards. The figure of the soldier-hero seems to be ambiguously placed in Pearman's text, in an 
attempt to overcome discrepancies between traditional heroic models and a changing reality.

The clash between the ideal and the real is of course not an exclusive merit of John Pearman, nor is it solely a nineteenth-century motive, though, as Furst argues, "the antihero figures most prominently in western literature since the French Revolution, and especially since the late nineteenth century" (1976: 5-6). In fact, there is not a definitive moment in which the notion of the anti-hero comes into existence. Being such an elusive and complex concept, its characterization would involve a detailed examination of "the whole milieu which produced it" (Furst, 1976, 5V) and, unfortunately, such undertaking would go beyond the objectives of this work. ${ }^{15}$ However, if the anti-hero is strictly defined as the antithesis of the hero, the literary trope may go back in time to Plautus' comedy Miles Gloriosus in 205 BC, in which the character of the 'braggart soldier' is first introduced. ${ }^{16}$ Indeed, the merging of an ideal with the reality of life is essential to classical comedy as, in Rubin's words, "the essence of comedy is incongruity" (1998: 109). And the fact that most mock-heroic narratives - from Plautus to Cervantes to Byron - have been "torn between strong sympathy and identification with the spirit and values of heroic adventure and comic awareness of its ludicrousness as much as its futility" (Salomon, 1976: 75) makes it possible to argue that perhaps the anti-hero was twinborn with the hero, that inherent to the classical heroic ideals was the human failure to achieve or at least to sustain those ideals. In Lamont's words, "paradoxically, the hero IS only as he IS NOT" (Lamont, 1976: 4). ${ }^{17}$

Of course, such statement has connotations for the evocation of the anti-heroic in The Radical Soldier's Tale, for there is no better embodiment of the conflict between the real and the ideal than that which exists in Pearman's memoir, initially based University Presson the worship of the exploits of the great men, but containing within itself many social and political contradictions. Rather than opposing the hero myth, Pearman tends to provide his soldier heroes with an increased moral complexity to make them useful as mirrors for social commentary and political critique. When the text does become anti-heroic, however, Pearman's style, unlike classical comedy, is not humorous in a comic sense, but rather bitterly ironic, tracing what appears to be the demise of the traditional hero to the anti-heroism of World War One.

Brombert's In Praise of Antiheroes acknowledges the complexity of the so-called "unheroic modes" (1999: 1) and links the anti-heroic to the paradoxical. In Brombert's view, the anti-heroic emerges from the heroic to subvert it as it "implies the negative presence of the subverted or negative model" (1999: 2). In this view, then, the anti-hero emerges as "a special category of heroes" (Lubin, 1968: 3). So much so that the boundaries between the heroic and the anti-heroic become blurred and more open to discussion. Similarly, Rutherford explores what he sees as a heroic-anti-heroic paradox by re-opening the question of what makes a hero and ultimately aiming at proving that heroism and anti-heroism coexist in the most complex and interesting works of war fiction, no matter what aspect of British national experience they are based on. Like some of the war writers reviewed in the works of Brombert and Rutherford, Pearman explores the odds, the value and price of heroism, exposing certain inconsistencies 
arising from its representation. Based on this, it would not be inappropriate to read The Radical Soldier's Tale from this heroic-anti-heroic perspective. John Pearman would be regarded as one of those "who at their best take full account of the complicated, contradictory nature of adult experience-who eschew ethical and psychological simplicities - but who none the less choose to treat heroic themes and reinvestigate heroic values" (Rutherford, 1978: 10).

Following this vein, Pearman's characters and themes seem to be hanging on a thin line, at times approximating the heroic simplicity of boy's adventure stories, at others articulating the disillusionment and anger of World War One accounts. In effect, as part of this dual or contradictory attitude, some of the soldiers depicted in the memoir appear to behave much like the stereotypical heroes in The Story of Cawnpore, while some others are made to play a more multifaceted role. In fact, Pearman's meditations on the complexity of his own experience prove that he is capable of surprise, contradiction and change, and of revealing situations of anxiety regarding the constraints, responsibilities and rewards of men at war. Unlike Thomson, John Pearman is anything but a simplistic stereotype. Given this profile, it is little wonder, then, that the physical attributes and moral dispositions - autonomy, achievement, stoicism, physical dominance and harm regarded as distinctive heroic virtues in The Story of Cawnpore, tend to give way to more humane feelings like deception, hypocrisy, emotional sensitivity and selfexpression in The Radical Soldier's Tale. Probably unwittingly, Pearman unsettles and undermines the ideals proposed by the Victorian hero myth and paves the way for a redefinition of the heroic ideal, one that embraces less rigid and fixed constructions and more personal and subjective ones.

Like Thomson's, Pearman's text also allows for a gender-oriented reading. But unlike the former, The Radical Soldier's Tale appears to attempt a departure from gender essentialist interpretations towards what masculinity scholarship (Gilmore, 1990: 1; Connell, 2000: 24; Kimmel 2000: 87-88) has called "constructionism" or "social construction of masculine identity." The Victorian ideal of "manliness" seems to be put to test. Rather than being universalized, the figure of soldier-hero tends to become the product of historical, cultural and social factors. Indeed, heroic masculinity appears to be socially constructed, culture-specific and class-bound. In fact the experience that Pearman recalls through the reconstruction of the changes made across his soldiering years, particularly the fractures in narrative between his public identity as an imperial soldier and his private oppositional self, are the clearest evidence that his masculine identity evolved and changed as a result of his experience of war.

Despite the solid ties between heroic masculinity and violence in The Story of Cawnpore and in nineteenth-century war literature in general, these ties are neither unchanging nor irreversible in The Radical Soldier's Tale. Though Pearman professes an initial affinity to imperial order and discipline, he soon realises that violence does not reaffirm masculinity and starts to show the gradual failure of this association. Through the rethinking of the implications of his working-class identity and the reconstruction of his past through war memories, Pearman begins to react negatively to soldiering, to 
battle, and to the taking of human life, questioning shared convictions and feeling like a puppet in the hands of the British government:

What is a Soldier A man forced down under the Brutalising machine of military life which presses out nature from the very veins and bones of its victims and shapes from the warm living flesh a puppet a tool a thing a Creature without eyes or ears or sence or will of its own - a playing for death a-missile in the merciless hand of the State for pomp and Vain Glory. (Steedman, 1988: 239)

Not only does Pearman learn that no cause is worth killing or dying for, he realises that he has been complicit in the violence of the empire against other human beings. If this contempt for the military reality of imperialism is set against his prior admiration of the idea of order and discipline, it is possible to assert not only the impact that reflection and reasoning had on his life but also the sense of uneasiness that flows from the realization of his fracturing sense of the self.

The existence of this singular tension between his performing a conservative function -with certain obligations attached to his public image as a soldier and a policeman - and his radical and republican ideology leads to a split between his private and public identity:

England boast of her freedom to the people. Why they have none if you want to see Freedom you must leave England and look out some were else.... But still I like Law and have always tried as a Soldier and a Policeman to maintain it and to keep University Press Disciplin.... (Steedman, 1988: 236)

Since the general expectation for his rank and file was to embrace imperial principles, the possibility of expressing radical thoughts seems almost inconceivable. The previous quote offers quite straightforward evidence that this is not necessarily Pearman's case. What is more, it is the disjuncture between the public and the private that helps Pearman extract meaning from his circumstances, get the skills to resolve communicational problems and be able to change his beliefs.

In fact the most emblematic aspect of the memoir as a whole is the writer's transformation of old events by new experiences. The basis for the release of past ingrained beliefs may have been founded on the reading of different sources while Pearman was a policeman in Buckinghamshire, mostly related with modern secularism: Shelley's Queen Mab, John Bedford Leno's Anti-Tithe Journal (1881) free thinking newspapers like the National Reformer, the Freethinker and the Republican, Bradlaugh's Impeachment of the House of Brunswick, Edward Royle's Radicals, Secularists and Republicans and Henry George's Progress and Poverty (Steedman, 1988: 86-103). It is the experience of reading from miscellaneous sources that seems to have changed and expanded the meaning of the events first described in a letter he sent to his mother in $1849 .{ }^{18}$

In this eight-page letter Pearman reviews six months of military campaign; yet, these same events are later expanded into a much longer account in the memoir. The 
letter appears to have been saved as a draft to remember historical events, whereas later accounts are rooted in the firm conviction of the ideas he had been exploring. Referring to how the soldier's readings transform the meaning of military events in India, Steedman claims, "he attributes to the soldiers he is describing a motive that embodies the cynicism about colonial enterprises that he had learned from the current condemnations of the secularist press" (Steedman, 1988: 84). Still, his writing does not reflect a deliberate intention to copy from the press but to establish relations between facts and learn from them:

John Pearman's writing is a reminder of the arrogance that lies in assuming that people 'get' their ideas from somewhere, that social and political analysis is always taken from above, from published sources. The 'Memoir' can stand as a description of how people respond to other people's ideas, in written form. But those ideas could not be responded to at all if they did not speak to what the listener or reader already knew, knew not out of some innate knowledge or experience, but from all that one encounters during a lifetime. (Steedman, 1988: 102)

In effect, though it is possible to trace the rhetorical strategies of the Chartist movement in the text (Steedman, 1988: 66), there is no clear evidence of Pearman's copying literally from his sources. In fact the memoir itself reflects the difficulties experienced when trying to incorporate new thoughts into old accounts as the process of interpretation and reordering of ideas came from somebody with little formal education and imperfect mastery of the English language. ${ }^{19}$

As mentioned above, the radical soldier was an assiduous reader while he was writing the memoir, yet, he was not a passive recipient of ideas. Secularism and freethought gave him the rhetorical tools to express what he already knew from other sources, arguments and lived experience. In fact it was his soldiering years in India which propelled him to rethink about the contradictions he lived with, contradictions which were grounded in his experience as a working-class soldier. Having realized that he had been "used in some way, by other people or by social forces" (Steedman, 1988: 7), Pearman comes to the conclusion that heroism is not defined by personal achievement but, as Steedman argues, "by what those dominant forms have said is a proper and fitting set of feelings for people in John Pearman's position to hold" (Steedman, 1988: 3). The Radical Soldier's Tale, then, stands as a reminder of Pearman's commitment to resist dominant ideas, but at the same time puts forward the ideal of a different, gentler manhood that does not seem to adjust to the shared Victorian stereotype. This way, the radical soldier operates as a counter-model within the system itself, challenging established discourses concerning both national identity and heroic masculinities. By bringing his inner convictions out into the text, Pearman becomes exposed and vulnerable to the readers. This suggests a take on masculinity to which Pearman can fully relate; one which is still heroic, though not in the conventional way, but within a more private and subjective sphere.

In order to clarify the above, it is important to make an observation about the term "masculinity" in opposition to "manliness." Roper (2005) uses the term "manliness" to 
refer to the nineteenth-century prevailing standard of manhood - associated in the previous section with the representation of the soldier-hero in The Story of Cawnore${ }^{20}$ and the word "masculinity" to connote the new significance that manhood acquires in the twentieth century. In fact Roper focuses "on self-perceptions and emotional sensibilities, that is, on subjectivity" (Roper, 2005: 345-6) to be able to explore how the Great War reconfigured the notion of masculinity around themes of pain and sacrifice. In his view, this is essential if "a properly grounded notion of 'identity,' which includes autobiographical experience" is to be pursued (Roper, 2005: 345). What is more, and most important, he refers to a stage between manliness and masculinity which, in his view, has to do with "the emergence, born of violent events in wartime, of a form of subjectivity that predates 'masculinity' as a fully fledged psychological identity" (Roper, 2005: 361). In this view, this "in-between state" is the direct consequence of the anxiety caused by the emotional experience of war - "of experience and not just language, being constitutive of identity" (Roper, 2005: 361) $-{ }^{21}$ and the reason why most Great War writers can be positioned precisely between manliness and masculinity.

Long before the Great War, John Pearman may have also found himself struggling between manliness and masculinity, these contrary impulses causing him to object to violence as a test for manhood and to the politics of imperialism, but at the same time trying "to keep University Press Disciplin" (Steedman, 1988: 236). Such a transitional state allows for a new understanding of Pearman's identity as the contradictory conjunction of forty years in uniform and the surprising realization that "man was not made to Slaughter is Fellow man" (Steedman, 1988: 192) manifesting itself in an antisystem attitude. Yet, at the same time, this discursive shift shows that Pearman was not ready to wholly redefine his masculine identity; as a consequence, he remained inbetween manliness and masculinity, being this complex of competing emotional impulses an essential constituent of his heroic self.

This peculiar attitude places Pearman at an advantage compared with his contemporaries. Not only was he different from the rest, the ideas he worked University Presson were revolutionary to his time and rank in the military. Pearman seems to be aware of his role in the British army: "he understood himself as one of imperialism's 'hired bravos,' that most despised of men, a soldier, and expressed considerable guilt about his role in India, and an even more passionate republicanism, radicalism and antiimperialism" (Steedman, 1995: 66). He is able to see what lied behind the imperialismChristianity connection - "The Gun sword \& Bayinet is the unity of the whole" (Steedman, 1988: 231) - and morally objects to it. In fact, his moral disapproval rests on a deep distrust of both the ethics of Christian Militarism and the colonialismimperialism that the history of his nation represented. Anticipating the growth of the Christian military ideal after the Indian Mutiny and its connection with imperial expansion, Pearman is able to see that ownership, rather than religion, was behind imperial venture:

You see the our next Step send a few soldiers they will soon show the way to become Christians. The next step is you must pay for the Loss you have put us to by being so stubborn as not to accept our views of religion. So you must pay the cost. Now comes the 
grand step Annexation of their Country and in a short time we send them a Bishop and all his host and you must pay for that likewise.... (Steedman, 1988: 196-197)

The connection Pearman establishes between greed and imperialism is thoughtprovoking and worthy of attention as it reflects the soldier's thorough understanding of British policy in India. But then again, he does not appear to deny the existence of the Christian God, as secularists would; he merely wants to prove that the law of God was used as a political argument to social and coercive ends. He seems determined to demonstrate that British institutions used Christian theology to justify the exploitation of people of different creeds and culture and the figure of the soldier-hero "as a tool of cultural and political hegemony" to maintain the status quo (Cooper and Hurcombe, 2009: 103)

Although the Christian militarism portrayed in mid-to late-nineteenth century war memoirs like Thomson's received increasingly widespread endorsement and helped most men understand themselves and their role in the world in a colonial setting, Pearman's exploration and questioning led towards a huge gulf between personal feelings and national interest instead. Where this gulf is revealed most clearly is in Pearman's reservations about the social connection in heroic action:

They hang one man who as Committed a small Crime and Praise other men who has Committed Large ones. Marlborough his 1000s and so did Wellington and so as many others and Alexander his Millions they are all Famous in history for Great men. But say Kill one man) are for what there is the rub) say Plunder or what ever it may be he must be Hangd he is a little Murderer, Marlborough Alexander Plundered Countries. But they were Great men) How many men were lost in Italy \& University Presson the Rhine for settling a King in Poland Both sides could not be right.... (Steedman, 1988: 202)

While Thomson is not expected to change, mature or develop as a result of his experience - as discussed in the previous section, he defines himself in relation to his enemy and justifies imperial violence as heroic duty; Pearman, on the other hand, moves beyond Christian militarism, writing to understand himself as somebody who has been shaped by the social and political world he is describing.

In this course of events, India provides Pearman with a sense of urgency that initiates a motive for change because it offers, as Boyle claims, "an instance of another religious culture different from and (it was believed) superior to that of the arrogant Christian west" (qtd in Steedman, 1988: 85). From his first description of his landing in India, an extraordinary and unique land where "every thing was new although strange to us" (Steedman, 1988: 114-115), to his later involvement with the native Indian, the soldier reveals an increasing attachment to the Other: "I was very fond of romeing about the Country and Converseing with the Natives - a people I always found very kind if properly treated by us But I am Compeled to say some of our men used the Poor native very bad..." (Steedman, 1988: 146). His getting closer to the Other progresses beyond a declaration of intent. The soldier is willing to take in a little piece of difference, ignoring the prejudices and ignorance which are the legacies of the Victorian 
hero myth, and finding common interests. So much so that he finally crosses the line between free speech and openly siding with the enemy when he condemns British imperialism through the mouth of the Other:

A True Musselman not a Mehomitian a Fire worshiper put me right on this Subject, [...] Do you think we gave you the Concessions you enjoy in our country of our Free will, Not at all. Your soldiers and sailors with their united arms was the argument that prevailed with us did you persuade the Sikhs to accept your rule of did you force them to do so at the point of your Guns [...] Is not your Gun your great civiliser your great persuader your one argument Why then are you not honest enough to make it your Idol and worship it) Gold is your God. (Steedman, 1988: 212-213) ${ }^{22}$

By identification with the subjects of British imperialism Pearman puts together the missing pieces in the puzzle of his working-class identity and alleviates his own feelings of oppression and outsiderness: "His mother was Welsh; he knew how the Irish felt; the 'Indian Blackman' and he were victims of the same system" (Steedman, 1988: 96). Pearman sees himself in these people and finally understands the perverse system that lies at the foundation of their exploitation, and his own: "I do think we should be thankful that we are of the poor Brotherhood for if there is such a Thing as sin we then know that the poor are with all their Temptations the most just and the most - righteous" (Steedman, 1988: 211).

Pearman's memories of the Other thus become a deliberate device for linking past experience with present understanding. His ethical sensibility puts him at a remove from the old order that prevails in India, something that is confirmed by his openness to the native Indian and his inability to accept the Sword and the Bible, which he condemns as a 'twin headed enemy' (Steedman, 1988: 60). Ultimately, it is through this process of seeing and understanding the Indian Black Man - "the True Musselman" (212) - crucially in Pearman's case, after spending time in India - that he finally finds out who he is, forced into the realisation by contrast with who he is not. Pearman does not seem to be able to reconcile the integrity of his identity as a working-class soldier with a national cause that he feels goes against who he really is. His narrative struggles to integrate what might be conceived as contrary impulses in Victorian Britain, that is to say, his wish to be true to himself with the self-effacing idea of heroic duty to the Queen.

Social vulnerability and lack of privilege provide Pearman with an ideal of social commitment to the working classes and identification with the enemy-Other which points towards a new conception of his own working-class masculinity. It is, in fact, possible to discern the incipient traces of a process tending to the redefinition of heroic masculinity in The Radical Soldier's Tale, a shift towards an alternative model based on relational or pacifist bonds. Though this is often perceived as a menace to gender identity by essentialists, in fact it refers to a free positioning with respect to unchanging and rigid binary opposites. At the end of the memoir, John Pearman has tested his manhood in the Sikh Wars; yet he seems to realize he can only become whole as a man once he acknowledges the Other. 


\section{Concluding remarks}

While Thomson's memoir depicts a single standard of heroic manhood adhering to the Victorian hero myth, Pearman's text challenges the traditional equation. The radical soldier suggests alternative approaches towards war, heroism and imperialism and reinterprets Thomson's more conventional representation of those subjects. His questioning attitude towards traditional heroic masculinity is founded not only on the changes he goes through - intellectually, politically and socially - as a result of the war, but also on his relation to the Indian native.

Because of the historical and literary context in which it emerges, Pearman's text can be regarded as pioneering. The radical soldier questions and re-evaluates British institutions and his own identity as a working-class soldier as none of his contemporaries have done. Pearman seems to have been dissatisfied, cornered, and even oppressed by the Establishment. He cries out, and even rebels in his writing. It is not in vain that he has been called radical by Steedman. Though she refers to the soldier's political sympathies for contemporary secularism and free thought, the term radical may also be interpreted in the modern sense of the word. Pearman can be seen as an oppositionist; and his ideas as revolutionary to his time and anticipatory of similar anxieties and inner conflicts reflected into the writings of soldiers of the Great War.

Nevertheless, Pearman's radical ideas never transcended the private sphere. The soldier was too disappointed with the system to play the war hero as Thomson did, yet he was not ready to publicly endorse the pacifist attitude. Although he flirted with both opposing forces, ultimately, he was nothing more than a simple man trying to understand himself and his circumstances in the context of mid-to late-nineteenth century imperial Britain.

\section{Notes}

1. In his essay "Heroism", Emerson also stresses the centrality of the heroic individual in nineteenth century American society and recognizes that the hero was primarily characterized by his "warlike attitude" which he defines as a "military attitude of the soul" asserted by the "ability to cope single-handed with the infinite army of enemies" (1856:227).

2. Graham Dawson revises what he calls the "hero industry", that is the "systematic organization of hero-worshipping in the publishing houses" (146). Eliza Looker's 'Live,' F.M Holmes's Four Heroes of India and George Barnett Smith's Heroes of the Nineteenth Century were published in this way, "either [as] a series of 'famous lives' about imperial soldiers [...]; or a collection of several, highly condensed lives within one volume" (Dawson, 1994: 146).

3. Among the most prominent titles were Charles Kingsley's Westward Ho!, Thomas Hughes' Tom Brown's School Days, the great works of Captain Frederick Marryat and Charles James Lever, Charlotte Yonge's Book of Golden Deeds, James Grant's Romance of War, and the popular boys' magazines The Boy's Own Paper and Chums.

4. The Story of Cawnpore: The Indian Mutiny 1857 was published in 1859 by R. Bentley. The "Memos of Late Sergeant John Pearman of H. Mgt 3rd or Kings Own Light Dragoons" was first edited and published by Sir George Charles Henry Victor Paget, Marquess of Anglesey, in 1968 - sixty years after John Pearman died - under the title of Sergeant 
Pearman's Memoirs and re-edited and published by Carolyn Steedman in 1988 as The Radical Soldier's Tale. Carolyn Steedman's edition is the one we have chosen to discuss in this article.

5. See page 9 for a detailed analysis of the interconnection between gender and heroism in Thomson's memoir.

6. The prolific nature of the publications on the topic and their particular style make it in fact possible to describe the 'Mutiny fiction' as a new literary genre. Quoting Gregg, Brantlinger argues: "in 1897, Hilda Gregg remarked that 'of all the great events of this century, as they are reflected in fiction, the Indian Mutiny has taken the firmest hold on to popular imagination." (Gregg qtd in Brantlinger, 1988: 199). And he adds, "at least fifty [novels] were written before 1900, and at least thirty more before World War II. There was also a deluge of eyewitness accounts, journal articles, histories, poems and plays dealing with the 1857-58 rebellion" (Brantlinger, 1988: 199).

7. All our quotes from Pearman's The Radical Soldier Tale in this article are literal transcriptions of the original source and are referenced as 'Steedman 1988.' Steedman "reproduces John Pearman's spelling, punctuation and grammatical structure with absolute fidelity", allowing the reader "to follow [Pearman's] progress both as a writer and as a thinker in a way that is not possible in an edited transcription" (Steedman, 1988: 111). Steedman also includes an introduction to the text that places the memoir in its textual, historical and political context.

8. Of the Indian Rebellion of 1857, English (1994: 169) writes: "The outnumbered and illequipped garrison of about a thousand Europeans (half were women or children), besieged at Cawnpore in June 1857, surrendered [to Nana Sahib] on the promise of a safe passage and boats to take the survivors to Allahabad. After the Europeans [under General Wheeler] had left their defences and had begun to board the boats at Satichaura Ghat on the Ganges, they were ambushed, and the boats were set on fire. Of approximately four hundred and fifty men, women and children at the ghat, more than half were killed in and around the boats on 27 June. Later the same day the surviving men were shot on the river bank. The remaining members of the garrison, about two hundred women and children, were taken back to the town and imprisoned in a building called the Bibighur, and there, on $15 \mathrm{July}$, as a relief column approached Cawnpore, those that had not already died were cut to pieces and, dead or dying, were thrown into a well. From the prisoners in the Bibighur there were no survivors."

9. The suffering and heroism of the British soldiers, women and children in the garrison, as well as Nana Sahib's villainy, were the hallmark of the most popular accounts of the Mutiny and the justification for the violent retaliatory attacks that followed the recapture of Kanpur by the British forces. Brantlinger reviews the general literary response to the events in India which he identifies as "calls for repression and revenge" against the enemy-Other (1988: 199).

10. See footnote 3 .

11. The enemy-other in The Story of Cawnpore was not a totally alien force but regular troops which had been trained by the British.

12. Known as Gordon of Khartoum, Charles George Gordon was a British army officer remembered for his campaigns in China and northern Africa and for his tragic and romanticised death (See George William Joy's painting General Gordon's Last Stand, 1885 in the Leeds City Art Gallery, UK.).

13. The Punjab is a territory situated in the border between India and Pakistan which had been extended and consolidated by Ranjit Singh in the early nineteenth century. By that time, the British East Indian Company's army had also expanded its dominions to the borders of the Punjab and was watching the events across the border with more than neighbourly interest. In 
1839, Ranjit Singh died and his kingdom became anarchic as different factions, among them a threatening army that claimed to be the Khalsa - the embodiment of the Sikh nation - engaged in a continuing fight for power and influence. This, together with the growth of the East India Company's military strength to counteract the threat of the Khalsa, increased the tension between the parties. The prevailing disorder provided the British with a good opportunity for direct intervention, which took place when the Sikh Army crossed the River Sutlej on 12 September 1845. This event marked the beginning of the First Anglo-Sikh War (1845-1846).

14. In the Introduction to the memoir, Steedman reviews other working-class military biographies contemporary to Pearman's. Among them, she mentions John Ryder's Four Years Service in India (1853), Thomas Quinney's Sketches of a Soldier's Life in India (1853), J.W. Baldwin's Narrative of Four Months Campaign in India (1853), James Gilling's The Life of a Lancer in the Wars of the Punjab (1855), Joseph Donaldson's Recollections of an Eventful Life (1856) and T. Gowing's A Soldier Experience (1884). Intriguingly, like the revenge responses, working-class autobiographies written before the Mutiny also use the romance format to account for battles and anecdotes of stoic soldier heroes speaking through the mouth of the Empire. Though written from an University Pressper-class perspective, W.D. Arnold's Oakfield (1854) is the only fictional account of the Sikh Wars that faintly approaches Pearman's. Although the novel is meant to advertise a British army with which the middle-class public could feel comfortable with, it reveals the contradictions of British social and political thinking in India and achieves, unintentionally perhaps, what John Pearman does deliberately.

15. Of the many books and articles devoted to the subject, Brombert, Victor (1999) In Praise of Antiheroes: Figures and Themes in Modern European Literature 1830-1980 ; Lubin, Harold (1968) Heroes and Anti-heroes: A Reader in Depth; Lamont, Rosette (1976) "From Hero to Anti-hero"; Kern, Edith (1958) "The Modern Hero: Phoenix or Ashes" and Rollin, Roger B (1973) Hero/Anti-Hero deserve special consideration.

16. In 1553, Nicholas Udall's Ralph Roister Doister emerges as the immediate successor of the classical models. Like Miles Gloriosus, Ralph Roister Doister is boastful both in terms of his abilities in the field of war and in love and also portrayed as a wooer. Roister Doister's image is that of the mock-hero of chivalric romances who is contrasted with the folk heroes from Arthurian legends as well as with classical and biblical heroes. Udall's adoption of the burlesque model in his combination of native elements with classical models anticipates the major traditions of Elizabethan comedy. The representation of character traits that counter heroism can also be seen in Shakespeare's Henry IV in the persona of Falstaff, the antithesis of Prince Hal the future King Henry V.

17. What is more, Lamont argues that in acknowledging humanity, the hero loses heroic identity: "But he the man whose acts will lead to mythicization, he may stand on the brink of immortality; yet he is mortal, therefore human" (1976. 3).

18. See the original letter content on pages 239-240 of Steedman's edition.

19. Pearman seems to have learned how to write English by actually doing so. Spelling mistakes were mostly due to this functional illiteracy; it appears that he wrote down words as they sounded phonetically and ignored proof-reading (Steedman, 1988: 72).

20. Also see John Tosh (2004) Manliness and Masculinities in Nineteenth-Century Britain and George L. Mosse (1996) The Image of Man: The Creation of Modern Masculinity.

21. Joana Bourke, on the other hand, argues that "the very act of narrating changes and formulates 'the experience." (2003: 121).

22. A detailed analysis of Pearman's bonding with the enemy-Other is presented in: Pividori, Cristina and Monnickendam, Andrew (2009) "The Soldier as Good Samaritan: 
bonding with the enemy in John Pearman's The Radical Soldier's Tale." Journal of War and Culture Studies, 2 (2): 105-119.

\section{References}

Anderson, Olive (1971): “The Growth of Christian Militarism in Mid-Victorian Britain." The English Historical Review 86 (338): 46-72.

Attridge, Steve (2003): Nationalism, Imperialism and Identity in Late Victorian Culture: Civil and Military Worlds. Basingstoke: Palgrave Macmillan.

Bourke, Joanna (2003): "Fear and Anxiety: Writing about Emotion in Modern History." History Workshop Journal 55 (1): 111-133.

Brantlinger, Patrick (1988): Rule of Darkness: British Literature and Imperialism, 1830-1914. New York: Cornell University Press.

Braudy, Leo (2003): From Chivalry to Terrorism: War and the Changing Nature of Masculinity. New York: Random House.

Brombert, Victor (1999): In Praise of Antiheroes: Figures and Themes in Modern European Literature 1830-1980. Chicago: University of Chicago Press.

Buchbinder, David (1994): Masculinities and Identities. Carlton: Melbourne University Press.

Campbell, Joseph 2004 (1949): The Hero with a Thousand Faces. New Jersey: Princeton University Press.

Carlyle, Thomas 2000 (1849): On Heroes, Hero-worship and the Heroic in History. New York: John Wiley.

Connell, R. W (2000): Masculinities. Sydney: Allen and Unwin.

Cooper, Nicola and Martin Hurcombe (2009): "Editorial: The Figure of the Soldier." Journal of War and Culture Studies 2 (2): 103-104.

Dawson, Graham (1994): Soldier Heroes: British Adventure, Empire and the Imagining of Masculinities. New York: Routledge.

Eldridge, C. C (1996): The Imperial Experience: From Carlyle to Forster. London: MacMillan Press.

Emerson, Ralph Waldo 1856 (1841). "Essay VIII: Heroism” in Essays: First Series. Boston: Phillips, Samson \& Co, 221- 240.

English, Barbara (1994): "The Kanpur Massacres in India in the Revolt of 1857." Past and Present 142 : 169-178.

Frye, Norhrop (1970): Anatomy of Criticism: Four Essays. 1957. New York: Atheneum.

Furst, Lilian R (1976): "Editor's Comments." The Anti-Hero: His Emergence and Transformations. Studies in the Literary Imagination 9 (1): 1-22.

Gilmore, David (1990): Manhood in the Making: Cultural Concepts of Masculinity. New Haven and London: Yale University Press.

Green, Martin (1980): Dreams of Adventure, Deeds of Empire. London: Routledge \& Kegan Paul.

Hourihan, Margery (1997): Deconstructing the Hero: Literary Theory and Children's Literature. London: Routledge.

Kimmel, Michael (1996): Manhood in America: A cultural history. New York: Free Press.

(2000): The Gendered Society. New York: Oxford University Press.

Lamont, Rosette (1976): "From Hero to Anti-hero." The Anti-Hero: His Emergence and Transformations. Studies in the Literary Imagination 9 (1): 1-22. 
Lubin, Harold (1968): Heroes and Anti-heroes: A Reader in Depth. San Francisco: Chandler Publishing Company.

MacDonald, Robert H (1994): The Language of Empire: Myths and Metaphors of Popular Imperialism, 1880-1918. Manchester: Manchester University Press.

MacKenzie, John M (1989): Imperialism and Popular Culture. Manchester: Manchester University Press.

— (2000) "The Iconography of the Exemplary Life: The Case of David Livingstone." In G. Cubitt and and A. Warren, eds., Heroic Reputations and Exemplary Lives. Manchester: Manchester University Press, 84-194.

Mosse, George L (1996): The Image of Man: The Creation of Modern Masculinity. Oxford: Oxford University Press.

Mukherjee, Rudrangshu (1990): "Satan Let Loose University Presson Earth: The Kanpur Massacres in India in the Revolt of 1857." Past and Present 128: 92-116.

Ouimette, Victor (1974): Reason Aflame: Unamuno and the Heroic Will. London: Yale University Press.

Paris, Michael (2000): Warrior Nation: Images of War in British Popular Culture, 1850-2000. London: Reaktion Books.

Pividori, Cristina and Monnickendam, Andrew (2009): "The Soldier as Good Samaritan: Bonding with the Enemy in John Pearman's The Radical Soldier's Tale." Journal of War and Culture Studies 2 (2): 105-119.

Roper, Michael (2005): “Between Manliness and Masculinity: The 'War Generation' and the Psychology of Fear in Britain, 1914-1950.” Journal of British Studies 44: 343-362.

Rubin, Louis D (1998): “The Great American Joke.” In What's so Funny? In N. Walker ed., Humor in American Culture. Wilmington: Scholarly Resources, 107-119.

Rutherford, Andrew (1978): The Literature of War: Five Studies in Heroic Virtue. London: MacMillan Press.

Salomon, Roger B (1976): “Mock-Heroes and Mock-Heroic Narrative: Byron's 'Don Juan' in the context of Cervantes." The Anti-Hero: His Emergence and Transformations. Studies in the Literary Imagination 9 (1): 69-86.

Segal, Robert (2000): Hero Myths. Oxford: Blackwell.

Steedman, Carolyn (1988): The Radical Soldier's Tale: John Pearman, 1819-1908. London: Routledge.

--- (1995): "Inside, outside, Other: Accounts of National Identity in the $19^{\text {th }}$ Century." History of the Human Sciences 8(4): 59-76.

Thomson, Mowbray 1995 (1859): The Story of Cawnpore: The Indian Mutiny 1857. London: Tom Donovan Publishing Ltd.

Tiger, Lionel (1969): Men in Groups. New York: Random House.

Tosh, John (2004): Manliness and Masculinities in Nineteenth-Century Britain. Harlow: Pearson Education.

Van Gennep, Arnold 1986 (1909): Los ritos de paso. Madrid: Taurus. 